\title{
STRUKTUR MODAL DAN VARIABEL YANG MEMPENGARUHINYA
}

\author{
Denny Asmas, Hasminidiarty, R. Adisetiawan \\ Fakultas Ekonomi Universitas Batanghari
}

\begin{abstract}
This research aims to analyze the factors affecting the capital structure of the company. The sample companies are companies incorporated in the Indonesia Stock Exchange's LQ45 period 2012-2017. Bound variable used in this research is the structure of assets, while non used is the company's size, profitability, liquidity, operating leverage and sales growth. Test tool used multiple regression test tools IE. The results obtained i.e. There are five free variables that influence partially against variable capital structure i.e. variable structure of assets, company size, profitability, liquidity and sales growth. While the operating leverage variable have no effect partially against the capital structure.
\end{abstract}

Key word: capital structure, structure of assets, company size, profitability, liquidity and sales growth

\section{PENDAHULUAN}

Pengembangan perusahaan dalam upaya untuk mengantisipasi persaingan yang semakin tajam dalam pasar yang semakin global seperti sekarang ini akan selalu dilakukan baik oleh perusahaan besar maupun perusahaan kecil. Upaya tersebut merupakan permasalahan tersendiri bagi perusahaan, karena menyangkut pemenuhan dananya yang diperlukan. Apabila suatu perusahaan dalam memenuhi kebutuhan dananya mengutamakan sumber dari dalam perusahaan, maka akan sangat mengurangi ketergantungannya kepada pihak luar. Apabila kebutuhan dana sudah sedemikian meningkatnya karena pertumbuhan perusahaan, dan dana dari sumber internal sudah digunakan semua, maka tidak ada pilihan lain selain menggunakan dana yang berasal dari luar perusahaan baik dari hutang (debt financing) maupun dengan mengeluarkan saham baru (external equity financing) dalam memenuhi kebutuhan dananya. (Asmas, 2016)

Oleh karena itu, pada prinsipnya setiap perusahaan membutuhkan dana untuk pengembangan bisnisnya. Pemenuhan dana tersebut berasal dari sumber internal ataupun sumber eksternal. Karena itu, para manajer keuangan dengan tetap memperhatikan cost of capital perlu menentukan struktur modal dalam upaya menetapkan apakah kebutuhan dana perusahaan dipenuhi dengan modal sendiri ataukah dipenuhi dengan modal asing. Dalam melakukan keputusan pendanaan, perusahaan juga perlu mempertimbangkan dan menganalisis kombinasi sumber-sumber dana ekonomis guna membelanjai kebutuhan-kebutuhan investasi serta kegiatan usahanya. Sebagaimana disebutkan Weston dan Brigham (1990) kebijakan mengenai struktur modal melibatkan trade off antara risiko dan tingkat pengembalian penambahan utang dapat memperbesar risiko perusahaan tetapi sekaligus juga memperbesar tingkat pengembalian yang diharapkan. Struktur modal yang optimal adalah struktur modal yang mengoptimalkan keseimbangan antara risiko dan pengembalian sehingga memaksimumkan harga saham. Untuk itu, dalam penetapan struktur modal suatu perusahaan perlu mempertimbangkan berbagai variabel yang mempengaruhinya. (Adisetiawan dan Asmas, 2012)

Masalah struktur modal merupakan masalah penting bagi setiap perusahaan, karena baik buruknya struktur modal perusahaan akan mempunyai efek yang langsung terhadap posisi finansialnya. Suatu perusahaan yang mempunyai struktur modal yang tidak baik, dimana mempunyai hutang yang sangat besar akan memberikan beban yang berat kepada perusahaan tersebut. Struktur modal merupakan cermin dari kebijaksanaan perusahaan dalam menentukan jenis sekuritas yang dikeluarkan, karena masalah struktur modal adalah erat hububugannya dengan masalah kapitalisasi, dimana disusun dari jenis-jenis funds yang membentuk kapitalisasi adalah struktur modalnya (Riyanto, 2001).

Krisis moneter yang melanda Indonesia tahun 1997 menjadikan perekonomian Indonesia memburuk. Tingkat suku bunga yang tinggi dengan menurunnya daya beli masyarakat menjadikan dunia bisnis ikut terpuruk. Banyak perusahaan mengalami kebangkrutan karena terlilit hutang. Mereka tidak mampu membayar hutang yang telah jatuh tempo dikarenakan nilai tukar rupiah yang sangat melemah terhadap dollar pada saat itu. Berdasarkan kondisi tersebut, perusahaan dalam menentukan struktur modalnya akan 
sangat memperhitungkan untung rugi yang akan didapatkan jika mereka menambah jumlah hutangnya. Dengan mengetahui faktor-faktor yang mempengaruhi struktur modal pada perusahaan-perusahaan yang pernah tergabung dalam LQ45 di Bursa Efek Indonesia, dapat membantu pihak manajemen perusahaan dalam menentukan pemenuhan kebutuhan dana untuk mencapai struktur modal yang optimal, dan juga para investor di pasar modal. Dengan demikian tujuan pihak manajemen perusahaan untuk memaksimumkan kemakmuran pemegang saham (pemilik) dapat tercapai. Mengingat keputusan pendanaan merupakan keputusan penting yang secara langsung akan menentukan kemampuan perusahaan untuk dapat bertahan hidup dan berkembang. Sehingga peneliti menduga bahwa terdapat pengaruh antara variabel tangible assets, firm size, operating leverage, profitabilitas, likuiditas, dan growth sales terhadap struktur modal. (Adisetiawan, 2011)

\section{TINJAUAN PUSTAKA \\ Teori Struktur Modal}

Salah satu isu penting yang harus dihadapi oleh para manajer keuangan menurut Sartono (2001) adalah hubungan antara struktur modal dengan nilai perusahaan. Struktur modal adalah merupakan perimbangan jumlah utang jangka pendek yang bersifat permanen, utang jangka panjang, saham preferen dan saham biasa. Menurut Weston dan Brigham (1990), setiap perusahaan menganalisis sejumlah faktor, dan kemudian menetapkan struktur modal yang ditargetkan. Target ini selalu berubah sesuai dengan perubahan kondisi, tetapi pada setiap saat dibenak manajemen perusahaan terdapat bayangan dari struktur modal yang ditargetkan tersebut. Jika tingkat hutang yang sesungguhnya berada dibawah target, mungkin perlu dilakukan ekspansi dengan melakukan pinjaman, sementara jika rasio hutang sudah melampaui target, barangkali saham perlu dijual.

Kebijakan mengenai struktur modal melibatkan trade off antara resiko dan tingkat pengembalianpenambahan hutang memperbesar tingkat pengembalian yang diharapkan. Resiko yang makin tinggi akibatnya membesarnya hutang cenderung menurunkan harga saham, tetapi meningkatkan tingkat pengembalian yang diharapkan akan menaikkan harga saham tersebut. Struktur modal yang optimal adalah struktur modal yang mengoptimalkan keseimbangan antara resiko dan pengembalian sehingga memaksimumkan harga saham. Menurut Husnan (2008), teori struktur modal menjelaskan apakah ada pengaruh perubahan struktur modal terhadap nilai perusahaan, seandainya keputusan investasi dan kebijakan deviden dipegang konstan. Dengan kata lain jika perusahaan mengganti sebagian modal sendiri dengan hutang atau sebaliknya apakah harga saham akan berubah. Tetapi kalau dengan merubah struktur modalnya ternyata nilai perusahaan berubah, maka akan diperoleh struktur modal yang terbaik. Struktur modal yang dapat memaksimumkan nilai perusahaan atau harga saham adalah struktur modal yang terbaik. Setiap keputusan pendanaan mengharuskan manajer keuangan untuk dapat mempertimbangkan manfaat dan biaya dari sumber-sumber dana yang akan dipilih karena masing-masing sumber dana mempunyai konsekuensi finansial yang berbeda.

Sumber pendanaan di dalam suatu perusahaan dibagi ke dalam dua kategori yaitu pendanaan internal dan pendanaan eksternal. Pendanaan internal dapat diperoleh dari sumber laba ditahan sedangkan pendanaan eksternal dapat diperoleh para kreditor atau yang disebut dengan hutang dari pemilik, peserta atau pengambil bagian dalam perusahaan atau yang disebut sebagai modal. Proporsi atau bauran dari penggunaan modal sendiri dan hutang dalam memenuhi kebutuhan dana perusahaan disebut struktur modal perusahaan. Teori struktur modal ini penting, karena (1) setiap ada perubahan struktur modal akan mempengaruhi biaya modal secara keseluruhan, hal ini disebabkan masing-masing jenis modal mempunyai biaya modal sendirisendiri; (2) besarnya biaya modal secara keseluruhan ini, nantinya akan digunakan sebagai cut of rate pada pengambilan keputusan investasi. Oleh karena itu struktur modal akan mempengaruhi keputusan investasi (Sutrisno, 2003).

Sedangkan menurut Awat dan Mulyadi (1996), berdasarkan sumbernya, ada tiga jenis dana yang dapat digunakan untuk membiayai operasi perusahaan, yaitu : penerbitan saham (equity financing), penerbitan obligasi sering disebut dengan pembelanjaan dari luar (external financing). Sedangkan penggunaan laba ditahan (retained earnings) disebut dengan pembelanjaan dari dalam perusahaan (internal financing). Dalam keputusan pembelanjaan ini akan ditentukan perimbangan yang optimal dari berbagai 
sumber dana yang akan digunakan. Yang dimaksud dengan struktur modal (capital structure) adalah perimbangan antara hutang jangka panjang dengan modal sendiri (saham). Teori struktur modal yang dikembangkan oleh beberapa ahli akan dijelaskan lebih mendetail pada bagian berikut ini, yaitu antara lain pendekatan Tradisional, pendekatan Modigliani dan Miller, pendekatan Laba Bersih atau Net Income (NI), pendekatan Laba Operasi Bersih atau Net Operating Income (NOI), Pecking Order dan Balanced Theory. Selain itu, Myers (1984) mengklasifikasikan berbagai macam faktor yang mempengaruhi struktur modal yaitu perusahaan yang mengikuti balanced theory dan perusahaan yang mengikuti pecking order theory.

\section{Pendekatan Tradisional}

Pendekatan tradisional berpendapat bahwa dalam pasar modal yang sempurna dan tidak ada pajak, nilai perusahaan (atau biaya modal perusahaan) dapat diubah dengan merubah struktur modalnya. Pendapat ini dominan sampai dengan awal tahun 1950-an. Menurut Husnan (2008) keadaan perusahaan menjadi lebih baik setelah perusahaan menggunakan hutang karena nilai perusahaan meningkat (atau biaya modal perusahaan menurun).

Menurut Sartono (2001), pendekatan ini mengasumsikan bahwa hingga tingkat leverage tertentu. Resiko perusahaan tidak mengalami perubahan. Sehingga baik $\mathrm{K}_{\mathrm{e}}$ (biaya modal sendiri) maupun $\mathrm{K}_{\mathrm{d}}$ (biaya hutang) relatif konstan. Namun demikian setelah leverage rasio utang tertentu, biaya hutang dan biaya modal sendiri meningkat. Peningkatan biaya modal sendiri ini akan semakin besar dan bahkan akan semakin besar daripada penurunan biaya karena penggunaan hutang yang lebih murah. Akibatnya biaya modal ratarata tertimbang pada awalnya menurun dan setelah leverage tertentu akan meningkat. Oleh karena itu nilai perusahaan mula-mula meningkat dan akan menurun sebagai akibat dari penggunaan utang yang semakin besar. Dengan demikian menurut pendekatan tradisional ini, terdapat struktur modal yang optimal untuk setiap perusahaan. Struktur modal yang optimal tersebut terjadi pada saat nilai perusahaan maksimum atau struktur modal yang mengakibatkan biaya modal rata-rata modal tertimbang minimum.

\section{Pendekatan Modigliani dan Miller}

Menurut Husnan (2008) mengutip dari artikel Modigliani dan Miller, menyebutkan bahwa dimungkinkan munculnya proses arbitrase yang akan membuat harga saham (nilai perusahaan) yang tidak menggunakan hutang maupun yang menggunakan hutang, akhirnya sama. Proses arbitrase muncul karena investor selalu lebih menyukai investasi yang memerlukan dana yang lebih sedikit tetapi memberikan penghasilan bersih yang sama dengan tingkat resiko yang sama pula. Dalam keadaan pasar modal sempurna dan tidak ada pajak, Modigliani dan Miller merumuskan bahwa biaya modal sendiri akan berperilaku sebagai berikut :

$\mathrm{K}_{\mathrm{e}}=\mathrm{K}_{\mathrm{eu}}+\left(\mathrm{K}_{\mathrm{eu}}-\mathrm{K}_{\mathrm{d}}\right)(\mathrm{B} / \mathrm{S})$

Dimana: $K_{\mathrm{e}}=$ biaya modal sendiri; $\mathrm{K}_{\mathrm{eu}}=$ biaya modal sendiri pada saat perusahaan tidak menggunakan hutang

$\mathrm{K}_{\mathrm{d}}=$ biaya hutang; $\mathrm{B}=$ nilai pasar hutang; $\mathrm{S}=$ nilai modal sendiri

Dengan demikian Modigliani dan Miller menunjukkan bahwa dalam keadaan pasar modal sempurna dan tidak ada pajak, maka keputusan pendanaan menjadi tidak relevan, artinya penggunaan hutang ataukah modal sendiri akan memberikan dampak yang sama bagi kemakmuran pemilik perusahaan. Dalam keadaan ada pajak, Modigliani dan Miller berpendapat bahwa keputusan pendanaan menjadi tidak relevan. Karena pada umumnya bunga yang dibayarkan dapat dipergunakan untuk mengurangi penghasilan yang dikenakan pajak (bersifat tax deductible). Dengan kata lain apabila ada dua perusahaan yang memperoleh laba operasi yang sama, tetapi yang satu menggunakan hutang sedangkan yang satunya tidak, maka perusahaan yang membayar bunga akan membayar pajak penghasilan yang lebih kecil. Penghematan membayar pajak merupakan manfaat bagi pemilik perusahaan, maka sudah tentu nilai perusahaan yang menggunakan hutang akan lebih besar dari pada perusahaan yang tidak menggunakan hutang. Pada prakteknya terdapat berbagai kritik berkenaan dengan pendekatan Modigliani dan Miller ini, antara lain :

- Pendekatan Modigliani dan Miller mengasumsikan bahwa tidak adanya biaya transaksi, maka poses arbitrase boleh dikatakan tanpa biaya, namun dalam realita bahwa komisi untuk para broker itu cukup tinggi (Brigham et al, 1999). 
- Pada awalnya Modigliani dan Miller mengasumsikan bahwa investor dan perusahaan memiliki akses yang sama terhadap lembaga keuangan. Akan tetapi para investor besar dimungkinkan memperoleh hutang dengan bunga yang lebih rendah sedangkan investor individu mungkin harus meminjam dengan tingkat bunga yang tinggi.

- Modigliani dan Miller juga mengasumsikan tidak ada konflik antar pihak dalam perusahaan atau agency problem yang dapat menimbulkan agency cost yang sangat besar (Brigham et.al, 1999).

- Tidak adanya pertimbangan adanya financial distress yang mungkin dihadapi perusahaan (Brigham et.al, 1999).

\section{Pendekatan Laba Bersih atau Net Income (NI)}

Menurut Sartono (2001), pendekatan laba bersih mengasumsikan bahwa investor mengkapitalisasi atau menilai laba perusahaan dengan tingkat kapitalisasi $(\mathrm{Ke})$ yang konstan dan perusahaan dapat meningkatkan jumlah hutangnya dengan tingkat biaya hutang $(\mathrm{Kd})$ yang konstan pula. Karena $\mathrm{Ke}$ dan $\mathrm{Kd}$ konstan, maka semakin besar jumlah hutang yang digunakan perusahaan, biaya modal rata-rata tertimbang (Ko) akan semakin kecil.

$\mathrm{K}_{\mathrm{o}}=\mathrm{D} /(\mathrm{D}+\mathrm{E}) \cdot \mathrm{K}_{\mathrm{d}}(1-\mathrm{T})+\mathrm{E} /(\mathrm{D}+\mathrm{E}) \mathrm{K}_{\mathrm{e}}$

Dimana : Ko = biaya modal rata-rata tertimbang; $\mathrm{D}=$ nilai pasar hutang perusahaan; $\mathrm{E}=$ nilai pasar saham biasa perusahaan; $\mathrm{Kd}=$ biaya hutang; $\mathrm{T}=$ tingkat pajak perusahaan; $\mathrm{Ke}=$ biaya modal sendiri

\section{Pendekatan Laba Operasi Bersih atau Net Operating Income (NOI)}

Sartono (2001) mengatakan bahwa pendekatan NOI ini mengasumsikan bahwa investor memiliki reaksi yang berbeda terhadap penggunaan hutang oleh perusahaan. Pendekatan ini melihat bahwa biaya modal rata-rata tertimbang konstan berapapun tingkat hutang yang digunakan oleh perusahaan. Pertama diasumsikan bahwa biaya hutang konstan seperti halnya dalam pendekatan laba bersih. Kedua, penggunaan hutang yang semakin besar oleh pemilik modal sendiri dilihat sebagai peningkatan resiko perusahaan. Oleh karenya tingkat keuntungan yang diisyratkan oleh pemilik modal sendiri akan meningkat sebagai akibat meningkatnya resiko perusahaan. Konsekuensinya biaya modal rata-rata tertimbang tidak mengalami perubahan dan keputusan struktur modal menjadi tidak penting.

\section{Pendekatan Balanced Theory dan Pecking Order Theory}

Berdasarkan balanced theory, perusahaan berusaha mempertahankan struktur modal yang ditargetkan dengan tujuan maksimum nilai pasar. Sedangkan pecking order theory, perusahaan berusaha menerbitkan sekuritas pertama berdasarkan internal yaitu : retained earning, kemudian hutang beresiko rendah dan terakhir ekuitas (Myers, 1984). Balanced theory yang selanjutnya disebut dengan Trade Off Theory sebagai penyeimbang manfaat dan pengorbanan yang timbul sebagai akibat penggunaan hutang. Sejauh manfaat lebih besar, hutang akan ditambah. Tetapi apabila pengorbanan karena menggunakan hutang sudah lebih besar, maka hutang tidak boleh lagi ditambah (Husnan, 2008). Myers (1984) mengatakan bahwa secara garis besar dapat disimpulkan bahwa balanced theory menganut pola keseimbangan antara keuntungan penggunaan dana dari hutang dengan tingkat bunga yang tinggi dan biaya kebangkrutan.

Asimetrik informasi, biaya transaksi dan biaya emisi merupakan faktor-faktor yang mempengaruhi pendanaan berdasarkan pecking order theory, sehingga cenderung mendorong perilaku pecking order theory (Myers, 1984). Untuk mengurangi berbagai biaya yang timbul dari pemilihan dana antara hutang atau ekuitas, para manajer akan menerbitkan sekuritas yang beresiko paling kecil. Pecking order cenderung memilih pendanaan sesuai dengan urutan resiko. Menurut Myers (1984), bahwa pecking order theory menyatakan beberapa hal antara lain :

- Perusahaan menyukai internal financing (pendanaan dari hasil operasi)

- Perusahaan mencoba menyesuaikan rasio pembagian deviden yang ditargetkan dengan berusaha menghindari perubahan pembayaran deviden secara drastis.

- Kebijakan deviden yang relatif segan untuk diubah, disertai untuk fluktuasi profitabilitas dan kesempatan investasi yang tidak bisa diduga, mengakibatkan bahwa dana hasil operasi kadangkadang melebihi kebutuhan dana untuk investasi, meskipun dalam kesempatan lain mungkin kurang. 
- Apabila pendanaan dari luar (external financing) diperlukan, maka perusahaan akan menerbitkan sekuritas yang paling aman terlebih dahulu. Yaitu dimulai dengan menerbitkan obligasi terlebih dahulu, kemudian diikuti dengan sekuritas yang berkarakteritik opsi (seperti obligasi konversi), baru kemudian bila masih belum mencukupi saham baru diterbitkan.

- Dalam teori pecking order, tidak ada satu target debt to equity ratio, karena ada dua jenis modal sendiri, yaitu internal dan eksternal. Modal sendiri berasal dari dalam perusahaan lebih disukai daripada modal sendiri yang berasal dari luar perusahaan.

Ada dua alasan mengapa dana eksternal lebih disukai dalam bentuk hutang daripada modal sendiri. Pertama, adalah pertimbangan biaya emisi. Biaya emisi obligasi akan lebih murah dari biaya emisi saham baru. Hal ini disebabkan karena penerbitan saham baru akan menurunkan harga saham lama. Kedua, manajer khawatir kalau penerbitan saham baru akan ditafsirkan sebagai kabar buruk oleh para pemodal dan membuat harga saham akan turun. Hal ini disebabkan antara lain oleh kemungkinan adanya asimetri informasi antara pihak manajer dengan pihak modal.

\section{Faktor-Faktor yang Mempengaruhi Struktur Modal}

Menurut Riyanto (2001), ada beberapa faktor yang mempengaruhi penentuan struktur modal yang optimal, yaitu :

1. Tingkat bunga, pada waktu perusahaan merencanakan pemenuhan kebutuhan modal adalah sangat dipengaruhi oleh tingkat suku bunga yang berlaku pada waktu itu. Tingkat bunga akan mempengaruhi pemilihan jenis modal apa yang akan ditarik, apakah perusahaan akan mengeluarkan saham ataukah obligasi.

2. Stabilitas dari earnings, suatu perusahaan yang mempunyai earnings yang stabil akan selalu dapat memenuhi kewajiban finansialnya sebagai akibat dari penggunaan modal asing. Sebaliknya perusahaan yang mempunyai earnings yang tidak stabil dan unpredictable akan menanggung resiko tidak dapat membayar beban bunga pada tahun atau keadaan yang buruk.

3. Susunan dari aktiva, sebanyakan perusahaan manufaktur dimana sebagian besar dari modalnya tertanam dalam aktiva tetap, akan mengutamakan pemenuhan kebutuhan modalnya dari modal yang permanen, yaitu modal sendiri, sedangkan modal asing sifatnya adalah sebagai pelengkap. Sementara itu, perusahaan yang sebagian besar dari aktivanya adalah aktiva lancar akan mengutamakan pemenuhan kebutuhan dananya dengan hutang jangka pendek.

4. Kadar resiko dari aktiva, tingkat atau kadar resiko dari setiap aktiva didalam perusahaan adalah tidak sama. Makin panjang jangka waktu penggunaan suatu aktiva didalam perusahaan, makin besar derajat resikonya. Dengan perkembangan dan kemajuan teknologi serta ilmu pengetahuan yang tiada henti, dalam artian ekonomis dapat mempercepat tidak digunakannya suatu aktiva, meskipun dalam artian teknis masih dapat digunakan.

5. Besarnya jumlah modal yang dibutuhkan, apabila jumlah modal yang dibutuhkan sangat besar, maka dirasakan perlu bagi perusahaan tersebut untuk mengeluarkan beberapa golongan sekuritas secara bersama-sama, sedangkan bagi perusahaan yang membutuhkan modal yang tidak begitu besar cukup hanya mengeluarkan satu golongan sekuritas saja.

6. Keadaan pasar modal, keadaan pasar modal sering mengalami perubahan disebabkan karena adanya gelombang konjungtur. Pada umumnya apabila gelombang meninggi (up-saving) para investor lebih tertarik untuk menanamkan modalnya dalam saham. Oleh karena itu, dalam rangka mengeluarkan atau menjual sekuritas-nya, perusahaan harus menyesuaikan dengan keadaan pasar modal tersebut.

7. Sifat manajemen, sifat manajemen akan mempunyai pengaruh langsung dalam pengambilan keputusan mengenai cara pemenuhan kebutuhan dana.

8. Besarnya suatu perusahaan, perusahaan yang lebih besar dimana sahamnya tersebar sangat luas akan lebih berani mengeluarkan saham baru dalam memenuhi kebutuhannya untuk membiayai pertumbuhan penjualannya dibandingkan perusahaan yang lebih kecil.

Selain itu, menurut Awat dan Mulyadi (1996), dalam penentuan struktur modal, perlu diperhatikan beberapa faktor yang dianggap dominan. Faktor-faktor tersebut antara lain : 
1. Tujuan perusahaan, Tujuan manajer adalah memakmurkan para pemegang saham, maka struktur modal yang optimal adalah yang dapat memaksimumkan nilai perusahaan. Sedangkan jika tujuan para manajer itu hanya memaksimumkan keamanan pekerjaannya maka struktur modal yang digunakan cukup terletak pada leverage rata-rata perusahaan lain yang sejenis.

2. Tingkat leverage untuk perusahaan yang sama dalam bidang usahanya.

3. Kemampuan dana intern

Penentu bagi dana internal adalah tingkat pertumbuhan pendapatan. Jika tingkat pertumbuhan pendapatan tinggi, memungkinkan bagi manajemen memperoleh dana yang lebih besar dari laba ditahan sehingga akan mengurangi dana pinjaman. Selain itu, kebijakan deviden juga berpengaruh terhadap kemampuan dana internal.

4. Perumusan kepemilikan dan pengendalian

Apabila saham yang ada dalam suatu perusahaan hanya dimiliki oleh sejumlah kecil pemegang saham, maka pihak manajemen akan segan untuk mengeluarkan saham baru.

5. Batas Kredit

Batasan kredit juga dipengaruhi oleh persepsi pihak kreditur tentang perusahaan.

6. Besarnya perusahaan

Suatu perusahaan yang berukuran besar akan lebih mudah memperoleh pinjaman dibandingkan dengan perusahaan kecil.

7. Pertumbuhan aktiva perusahaan

Pertumbuhan aktiva dapat dijadikan indikator bagi kesempatan pengembangan perusahaan pada waktu yang akan datang. Jadi pertumbuhan aktiva dapat memberikan gambaran bagi kebutuhan dana total dalam suatu perusahaan.

8. Stabilitas pendapatan atau earnings

Seperti diketahui bahwa variabilitas pendapatan dapat dijadikan ukuran bagi resiko bisnis. Kreditur cenderung bersedia memberikan pinjaman kepada perusahaan yang memiliki pendapatan yang stabil.

9. Biaya Hutang

Jika biaya hutang lebih besar dari rentabilitas aktiva, maka penambahan hutang akan memberikan efek yang kurang mendukung bagi rentabilitas modal sendiri.

10. Biaya Modal Sendiri

Biaya modal sendiri (cost of equity) direfleksikan melalui harga saham. Naik turunnya harga saham menunjukkan harapan bagi pembelanjaan modal sendiri yang murah ataupun mahal, sehingga dapat membuat penarikan hutang yang kurang maupun lebih menarik.

11. Tarif Pajak

Berhubung pembayaran bunga merupakan tax deductable bagi perusahaan, maka pembelanjaan dengan menggunakan hutang akan menjadi lebih menarik.

12. Perkiraan Tingkat Inflasi

Tingkat inflasi akan mempengaruhi permintaan dan penawaran dana. Dalam keadaan inflasi yang tinggi perusahaan menyenangi pembelanjaan melalui hutang.

13. Kemampuan sumber dana pinjaman

Penawaran bagi dana pinjaman dipengaruhi oleh kebijaksanaan pemerintah. Berkurangnya ketersediaan dana ekstern akan mengakibatkan pembelanjaan hutang menjadi mahal.

14. Kebiasaan Umum di Pasar Modal.

Kecenderungan investor yang lebih menyenangi surat-surat berharga dari bank, perusahaan asuransi dan public utility akan menyulitkan perusahaan untuk segera mengubah struktur modalnya.

15. Struktur Aktiva

Jika komposisi aktiva suatu perusahaan bersifat capital intensive berarti perusahaan mengutamakan pembelanjaan modal sendiri, artinya modal pinjaman hanya merupakan pelengkap, terutama bagi pembiayaan modal kerja.

Selain teori diatas tentang faktor-faktor yang mempengaruhi struktur modal, masih banyak lagi yang mengemukakan pendapatnya tentang hal tersebut. Dari beberapa faktor yang dipilih oleh mereka, pada umumnya mempunyai kesamaan dengan latar belakang alasan yang hampir sama pula. 


\section{Tinjauan Penelitian Terdahulu.}

1. Penelitian yang hampir sama juga dilakukan oleh Rajan \& Zingales (1995), yaitu meneliti tentang faktor-faktor yang mempengaruhi pemilihan struktur modal dinegara-negara G-7, dimana faktor-faktor tersebut telah diidentifikasi oleh Harris \& Raviv (1991). Variabel-variabel tersebut adalah tangible assets, rasio market to book, ukuran perusahaan dan profitabilitas. Hasil penelitian tersebut merupakan konsistensi dari banyak penelitian sebelumnya di Amerika Serikat. Penelitian ini membuktikan bahwa tangibility, ukuran perusahaan, mempunyai hubungan positif dengan struktur modal. Sedangkan profitabilitas memiliki hubungan negatif terhadap struktur modal perusahaan.

2. Pada tahun 2001, Ozkan telah melakukan penelitian tentang Faktor-faktor yang Mempengaruhi Struktur Modal. Penelitian dilakukan selama periode 1984-1996 dengan sampel 390 perusahaan. Penelitian ini dilakukan dengan tujuan untuk mengetahui faktor-faktor yang mempengaruhi struktur modal. Hasil penelitian menyebutkan bahwa ukuran perusahaan mempunyai hubungan positif terhadap struktur modal, tingkat non-debt tax shield, likuiditas perusahaan dan profitabilitas mempunyai hubungan negatif terhadap struktur modal.

3. Penelitian yang dilakukan oleh Sartono dan Sriharto (1999) dengan judul penelitian "Faktor-faktor yang Mempengaruhi Struktur Modal" (perusahaan manufaktur di BEJ tahun 1994-1997). Sartono meneliti faktor-faktor yang mempengaruhi struktur modal pada 61 perusahaan manufaktur yang telah go public di Bursa Efek Jakarta. Variabel-variabel yang digunakan dalam penelitian ini adalah Debt/total Assets (DTA), Fixed Assets/Total Assets (FTA), Market to Book Ratio (MTB), In Net Sales (InSales), dan EBIT/Total Assets (ROA), Real Sales Growth Rate (GRS), dan Selling Expense/Sales (SES). Hasil penelitian menjelaskan bahwa dalam periode waktu tahun 1994-1997 hanya faktor Size, Profitabilitas dan Growth yang terbukti mempengaruhi struktur modal. Sedangkan faktor tangibility of assets, growth opportunities dan uniques tidak terbukti mempengaruhi struktur modal.

\section{METODE}

Sampel yang digunakan dalam penelitian ini adalah perusahaan-perusahaan yang tergabung dalam LQ45 di Bursa Efek Indonesia periode 2012-2017 yang listing laporan keuangannya lengkap, tidak bergerak dalam bidang jasa keuangan dan perbankan, dan selama periode pengamatan tidak memiliki laba bersih negatif.

Pada penelitian ini, peneliti akan menggunakan variabel dependen dan variabel Independen.

a. Variabel Dependen

Dalam penelitian ini yang menjadi variabel dependen adalah Struktur Modal. Struktur Modal dalam hubungannya dengan nilai perusahaan adalah merupakan perimbangan jumlah utang jangka pendek yang bersifat permanen, utang jangka panjang, saham preferen dan saham biasa (Sartono, 2001). Struktur Modal dapat diukur dengan rasio Debt to Total assets (DTA), diformulasikan sebagai berikut :

Rasio Debt to Total Assets = Total Liabilities/Total Assets x 100\%

b. Variabel Independen

Dalam penelitian ini akan digunakan 6 (enam) variabel independen yaitu :

1. Tangible Assets (FTA)

Tangible Assets (FTA) pada penelitian ini diproyeksikan antara Fixed Asset (FA) terhadap Total Asset (TA). Diformulasikan sebagai berikut :

Rasio Tangible Assets = Fixed Assets/Total Assets x 100\%

2. Firm Size (SIZE)

Firm size (SIZE) diproyeksikan antara LogNatural dari total assets. Diformulasikan :

$S I Z E=$ LnTA

3. Operating Leverage (DOL)

Operating Leverage (DOL) yaitu tingkat biaya modal yang dioperasikan. Diformulasikan sebagai berikut :

Degree of Operating Leverage = perubahan EBIT/perubahan penjualan x 100\%

4. Profitabilitas (NPM) 
Profitabilitas (NPM) adalah tingkat keuntungan bersih yang mampu dihasilkan perusahaan dalam menjalankan operasinya. Profitabilitas perusahaan dalam penelitian ini diukur dengan rasio net proft margin yang menghitung sejauhmana kemampuan perusahaan menghasilkan laba bersih pada tingkat penjualan tertentu. Diformulasikan sebagai berikut:

Net Profit Margin $(\mathrm{NPM})=$ Net Profit/Net Sales $\mathrm{x} 100 \%$

5. Likuiditas (CR)

Likuiditas (CR) diproyeksikan antara current assets dan current liabilities. Diformulasikan sebagai berikut :

Current Ratio $=$ Current Assets/Current Liabilities x $100 \%$

6. Growth Sales (GS)

Growth Sales (GS) dalam penelitian ini dihitung dengan menggunakan prosentase kenaikan atau penurunan penjualan dari suatu periode ke periode berikutnya. Diformulasikan sebagai berikut:

Pertumbuhan $\mathrm{n}=\{$ Penjualan $(\mathrm{t})$ - Penjualan $(\mathrm{t}-1)\} /$ Penjualan $(\mathrm{t}-1)$

\section{Model Analisis}

Penelitian ini akan menggunakan metode regresi linier berganda untuk analisis impact dari variable independent terhadap variable dependent. Dengan model penelitian sebagai berikut:

DTA $=\mathrm{a}+\mathrm{b} 1$ FTA + b2 SIZE + b3 DOL + b4 CR + b5 GS + b6 NPM + e

Dimana : DTA = struktur modal; $\mathrm{a}=$ intercept atau konstanta; b1,b2,b3,b4,b5,b6 = koefisien regresi variabel FTA, SIZE, DOL, CR, GS, NPM; FTA = struktur aktiva atau tangible assets; SIZE = ukuran perusahaan; $\mathrm{DOL}=$ operating leverage $; \mathrm{CR}=$ likuiditas $; \mathrm{GS}=$ pertumbuhan penjualan; $\mathrm{NPM}=$ profitabilitas $; \mathrm{e}=$ error

\section{Teknik Analisis}

Alat regresi yang digunakan adalah menggunakan alat bantu SPSS 19.0., dan sebelum melakukan regresi linier berganda terlebih dahulu dilakukan pengujian asumsi klasik. Uji asumsi klasik yang dipakai dalam penelitian ini ada 4 (empat), di antaranya :

a. Normalitas

Menguji apakah dalam sebuah model regresi. variabel bebas dan variabel terikatnya atau keduanya mempunyai distribusi normal ataukah tidak. Model regresi yang baik adalah distribusi data normal atau mendekati normal. Cara mendeteksinya dengan melihat penyebaran data (titik) pada sumbu diagonal dari grafik Normal P-P Plot of Regression. Jika menyebar di sekitar garis diagonal dan mengikuti arah garis diagonal. maka memenuhi asumsi normalitas. Sebaliknya. jika tidak mengikuti arah garis diagonal berarti tidak memenuhi asumsi normalitas.

b. Uji Autokorelasi (Independence of Errors)

Uji autokorelasi untuk mengetahui apakah data penelitian yang disusun time series terjadi korelasi otomatis, atau munculnya suatu data dipengaruhi oleh data sebelumnya. Data penelitian yang dikehendaki adalah tidak terjadi autokorelasi. Uji autokorelasi menggunakan uji Durbin Watson (uji DW), pendeteksian ada tidaknya gejala autokolerasi menurut Gujarati (2006, 428) adalah sebagai berikut : Jika angka D-W di bawah -2, berarti ada autokorelasi negatif; Jika angka D-W di antara -2 sampai 2, berarti tidak ada autokorelasi; Jika angka D-W di atas +2 , berarti ada autokorelasi positif;

c. Uji Multikolineritas (Multiko)

Uji multiko digunakan untuk menunjukkan ada tidaknya hubungan linier yang kuat di antara variabelvariabel bebas dalam model regresi. Data penelitian yang dikehendaki dalam persamaan regresi linier adalah tidak terjadi multiko. Uji multiko penelitian ini menggunakan Collinearity Statistics. Apabila nilai tolerance < 0,1 dan VIF $>10$ (Variance Inflation Factor) mengindikasikan terjadi multicollinearity (Gujarati, 2006; 366).

d. Uji Heteroskedastisitas (Hetero)

Uji Heteroskedastisitas dilakukan dengan cara grafik, dari grafik Scatterplot yang disajikan SPSS, yang terlihat titik-titik menyebar secara acak tidak membentuk sebuah pola tertentu yang jelas serta tersebar baik di atas maupun di bawah angka nol pada sumbu Y. Hal ini berarti tidak terjadi heteroskedastisitas pada model regresi. (Gujarati, 2006, 390). 


\section{Pengujian Hipotesis}

Prosedur pengujian hipotesis ditetapkan sebagai berikut :

a) Uji Hipotesis secara parsial : uji t

Uji t digunakan untuk menguji signifikan-tidaknya pengaruh variabel-variabel bebas secara parsial terhadap variabel terikat,

Batasan Penolakan $\mathrm{H}_{0}$ : apabila $\mathrm{t}_{\text {hitung }}>\mathrm{t}_{\text {tabel }}$ dan sig. $<0,05$, maka $\mathrm{H}_{0}$ ditolak sehingga hipotesis yang diajukan terbukti.

b) Uji Hipotesis secara simultan : uji F

Uji F digunakan untuk menguji signifikan-tidaknya pengaruh variabel-variabel bebas secara simultan terhadap variabel terikat.

Batasan Penolakan $\mathrm{H}_{0}$ : apabila $\mathrm{F}_{\text {hitung }}>\mathrm{F}_{\text {tabel }}$ dan sig. $<0,05$, maka $\mathrm{H}_{0}$ ditolak sehingga hipotesis yang diajukan terbukti.

\section{HASIL}

Analisis yang digunakan dalam penelitian ini adalah analisis regresi linier berganda. Untuk mengetahui apakah data yang digunakan memenuhi asumsi-asumsi, maka dilakukan uji asumsi terlebih dahulu. Analisis yang digunakan dalam penelitian ini adalah analisis regresi linier berganda. Untuk mengetahui apakah data yang digunakan memenuhi asumsi-asumsi, maka dilakukan uji asumsi terlebih dahulu.

\section{Uji Normalitas}

Output grafik normal P-P Plot of regression pada gambar 1 terlihat bahwa, penyebaran data (titik) pada sumbu mengikuti arah garis diagonal dari grafik, sehingga dapat dikatakan bahwa dalam model regresi terdiri atas variabel bebas, variabel terikat atau keduanya mempunyai distribusi normal.

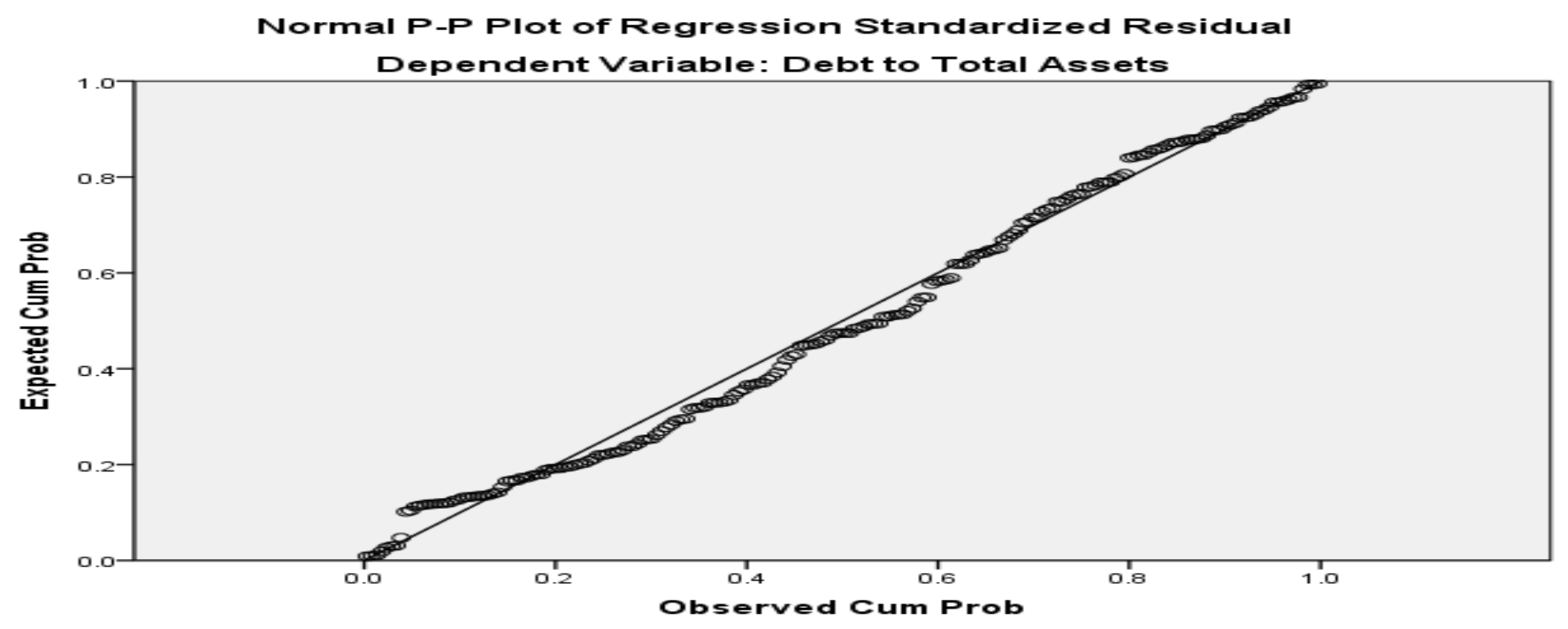

Gambar 1.

Uji Normalitas Model Penelitian

\section{Uji Multikolinearitas}

Tabel 1.

Hasil Uji Multikolinearitas Model Penelitian

\begin{tabular}{|c|c|c|}
\hline \multirow{2}{*}{ Variabel } & \multicolumn{2}{|c|}{ Collinearity Statistics } \\
\hline & Tolerance & VIF \\
\hline Tangible Assets & 0,847 & 1,181 \\
\hline Firm Size & 0,824 & 1,214 \\
\hline Operating Leverage & 0,978 & 1,023 \\
\hline
\end{tabular}




\begin{tabular}{lrr}
\hline Likuiditas & 0,863 & 1,159 \\
Growth Sales & 0,966 & 1,036 \\
Profitabiltas & 0,935 & 1,069 \\
\hline
\end{tabular}

Sumber: data olahan

Pada Tabel 1 menunjukkan nilai Tolerance $>0,1$ dan VIF $<10$. Apabila nilai tolerance $<0,1$ dan VIF $>10$, mengindikasikan terjadi multicollinearity. Sehingga dapat disimpulkan pada model penelitian ini no collenearity atau problem multikolinearity tidak terjadi.

\section{Uji Autokorelasi}

Dari hasil penelitian yang terlihat pada Tabel 2 didapat nilai DW 1,242 yang berada diantara $-2<$ DW $<+2$. Hal ini menunjukkan tidak terjadi autokorelasi. Dengan demikian dapat disimpulkan model penelitian ini memenuhi asumsi bebas autokorelasi.

Tabel 2

Hasil Uji Autokorelasi

Variabel Durbin Watson (DW) statistic

Tangible Assets, Firm Size, Operating Leverage, Likuiditas, Growth Sales,

Profitabiltas

1,242

Sumber: data olahan

\section{Uji Heteroskedasitas}

Uji Heteroskedastisitas dilakukan dengan cara grafik scatterplot. Dari gambar 2. Grafik scatterplot terlihat titik-titik menyebar secara acak tidak membentuk sebuah pola tertentu yang jelas serta tersebar baik di atas maupun di bawah angka nol pada sumbu Y. Hal ini dapat disimpulkan bahwa persamaan regresi model penelitian ini memenuhi asumsi bebas heteroskedastisitas. Dari uji asumsi klasik yang telah dilakukan bahwa dalam penelitian ini memenuhi uji asumsi-asumsi analisa regresi berganda sehingga data layak digunakan dalam penelitian.

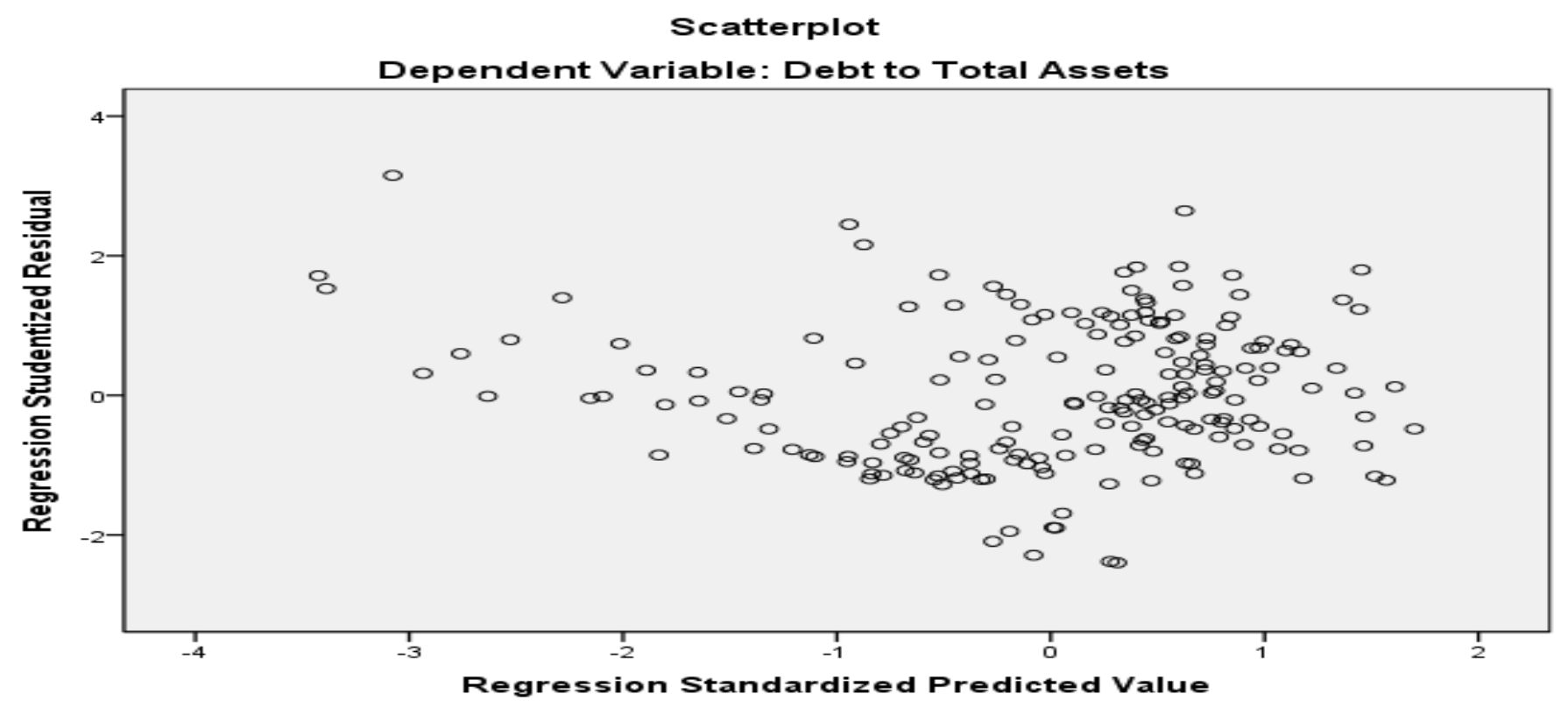

Gambar 2.

Grafik Scatterplot Model Penelitian

\section{Pengujian Hipotesa}

a. Uji F atau Pengaruh secara Simultan 
Uji F ini bertujuan untuk membuktikan signifikan atau tidaknya, pengaruh antara variabel bebas dan variabel terikat secara serempak dan membuktikan apakah hipotesa yang diajukan diterima atau ditolak. Pengujian dilakukan dengan dasar pengambilan keputusan jika probabilitas $>0,05$, maka $\mathrm{H}_{0}$ diterima dan jika probabilitas $<0,05$, maka $\mathrm{H}_{0}$ ditolak.

Hasil regresi linier model penelitian dapat dilihat pada Tabel 3 di bawah ini :

Tabel 3

Uji F pada Model Penelitian

\begin{tabular}{|c|c|c|c|c|c|}
\hline Variabel Tergantung & $\mathrm{R}^{2}$ & Adjusted $\mathrm{R}^{2}$ & $\mathrm{~F}$ & Sig. & Keterangan \\
\hline Struktur Modal & 0,503 & 0,487 & 32,215 & $0,000^{\mathrm{a}}$ & Signifikan \\
\hline
\end{tabular}

Sumber : Data Olahan

Berdasarkan hasil uji $\mathrm{F}$ diperoleh nilai probabilitas $\mathrm{F}_{\text {hitung }}>0,05$; maka $\mathrm{H}_{0}$ ditolak, berarti hipotesis yang diajukan dalam penelitian ini terbukti. Dengan demikian ada pengaruh yang signifikan antara variabelvariabel tangible assets (FTA), firm size (SIZE), operating leverage (DOL), profitabilitas (NPM), likuiditas (CR), dan growth sales (GS) secara bersama terhadap struktur modal (DTA). Sedangkan koefisien determinasi simultan yang merupakan hasil pengkuadratan koefisien korelasi menunjukkan persentase pengaruh variabel bebas secara simultan terhadap variabel terikat. Berdasarkan hasil perhitungan SPSS yang disajikan pada tabel 2 dapat diketahui bahwa nilai koefisien korelasi (R) adalah 0,503 artinya hubungan antara variabel bebas terhadap variabel terikat adalah signifikan dan positif. Dimana perubahan yang terjadi pada variabel bebas akan diikuti oleh perubahan pada variabel terikatnya. Persentase perubahan variabel bebas terhadap variabel terikat yang ditunjukkan oleh koefisien determinasi simultan $\left(\mathrm{R}_{\text {squared }}\right)$ adalah sebesar 50,3 persen. Sedangkan sisanya sebesar 49,7 persen dipengaruhi oleh variabel lain diluar penelitian ini. Tetapi karena pada penelitian ini variabel bebas yang digunakan 6 variabel, maka nilai determinasi yang digunakan bukan $\mathrm{R}_{\text {squared }}$ melainkan adjusted $R$ squared yaitu sebesar 0,487 atau 48,7 persen.

\section{b. Uji t atau Pengaruh Secara Parsial}

Uji t ini bertujuan untuk membuktikan signifikan atau tidaknya, pengaruh antara variabel bebas dan variabel terikat secara parsial sekaligus membuktikan apakah hipotesa yang diajukan diterima atau ditolak. Pengujian dilakukan dengan dasar pengambilan keputusan jika probabilitas $>0,05$, maka $\mathrm{H}_{0}$ diterima dan jika probabilitas $<0,05$, maka $\mathrm{H}_{0}$ ditolak.

Tabel 4.

Uji t pada Model Penelitian

\begin{tabular}{lrrrl}
\hline \multicolumn{1}{c}{ Variabel } & Coefficient & t-Statistik & Sig. & Keterangan \\
\hline Tangible Assets & $-0,124$ & $-2,231$ & 0,027 & Signifikan \\
Firm Size & 0,218 & 3,887 & 0,000 Signifikan \\
Operating Leverage & $-0,038$ & $-0,738$ & 0,461 & Tidak Signifikan \\
Likuiditas & $-0,565$ & $-10,294$ & 0,000 & Signifikan \\
Growth Sales & 0,114 & 2,186 & 0,000 Signifikan \\
Profitabiltas & $-0,234$ & 4,435 & 0,000 Signifikan \\
\hline
\end{tabular}

Sumber : data olahan

Dari hasil regresi linier pada Tabel 4 sebelumnya dapat dijelaskan sebagai berikut :

- Koefisien regresi $\left(\mathrm{x}_{1}, \mathrm{x}_{2}, \mathrm{x}_{4}, \mathrm{x}_{5}, \mathrm{x}_{6}\right)$ dengan sig. $<0,05 ; \mathrm{H}_{0}$ ditolak, berarti hipotesis yang diajukan dalam penelitian ini tidak terbukti. Dengan demikian ada pengaruh yang signifikan antara variabelvariabel tangible assets (FTA), firm size (SIZE), operating leverage (DOL), profitabilitas (NPM), likuiditas (CR), dan growth sales (GS) secara bersama terhadap struktur modal (DTA).

- Koefisien regresi $\left(\mathrm{x}_{3}\right)$ dengan sig. $>0,05 ; \mathrm{H}_{0}$ gagal ditolak, berarti tidak ada pengaruh yang signifikan antara variabel-variabel tangible assets (FTA), firm size (SIZE), operating leverage (DOL), profitabilitas (NPM), likuiditas (CR), dan growth sales (GS) secara bersama terhadap struktur modal (DTA). 


\section{Analisa Regresi}

berikut:

Tabel 4 di atas dapat diperoleh model persamaan regresi berganda yang bias dibentuk sebagai

DTA $=0,000-0,124$ FTA + 0,218 SIZE - 0,038 DOL - 0,565 CR + 0,114 GS - 0,234 NPM

Dari model regresi berganda yang diperoleh dari hasil pengujian akan dijelaskan pengaruh variabel independen secara parsial (satu per satu) terhadap variabel dependen yaitu Struktur Modal (DTA).

a. Variabel Tangible Asset (FTA)

Koefisien regresi tangible asset sebesar -0,124; menunjukkan bahwa variabel tangible asset berpengaruh negatif (berlawanan arah) terhadap struktur modal. Apabila variabel tangible asset mengalami kenaikan sebesar satu persen, maka struktur modal akan mengalami penurunan sebesar 12,4 persen dengan asumsi variabel firm size, operating leverage, profitabilitas, likuiditas, dan growth sales dianggap konstan. Dengan kata lain, jika tangible asset meningkat, maka akan menurunkan jumlah struktur modal, struktur modal dalam hal ini mencerminkan hutang perusahaan tersebut. Hasil penelitian ini tidak konsisten dengan penelitian sebelumnya Rajan \& Zingales (1995) dan Sartono dan Sriharto (1999) yang mana pada penelitian Rajan \& Zingales (1995) tangibility mempunyai pengaruh positif dengan struktur modal, sedangkan pada penelitian yang dilakukan oleh Sartono dan Sriharto (1999) faktor tangibility of assets tidak memiliki pengaruh terhadap struktur modal.

b. Variabel Firm Size (SIZE)

Koefisien regresi firm size sebesar 0,218; menunjukkan bahwa variabel firm size berpengaruh positif (searah) terhadap struktur modal. Apabila variabel firm size mengalami kenaikan sebesar satu persen, maka struktur modal akan mengalami peningkatan sebesar 21,8 persen dengan asumsi variabel tangible asset, operating leverage, profitabilitas, likuiditas, dan growth sales dianggap konstan. Hal ini berarti semakin besar ukuran perusahaan yang direfleksikan dari total aktiva, maka semakin besar jumlah struktur modal (dalam hal ini utang) perusahaan tersebut. Hasil penelitian ini konsisten dengan penelitian sebelumnya, yaitu Rajan \& Zingales (1995), Ozkan (2001), Sartono dan Sriharto (1999) yang mana pada penelitian sebelumnya variabel ukuran perusahaan mempunyai pengaruh positif dengan struktur modal.

c. Variabel Operating Leverage (DOL)

Koefisien regresi operating leverage sebesar -0,038; menunjukkan bahwa variabel operating leverage mempunyai pengaruh signifikan terhadap struktur modal.

d. Variabel Likuiditas (CR)

Koefisien regresi likuiditas sebesar -0,565; menunjukkan bahwa variabel likuiditas berpengaruh negatif (berlawanan arah) terhadap struktur modal. Apabila variabel likuidtas mengalami kenaikan sebesar satu persen, maka struktur modal akan mengalami penurunan sebesar 56,5 persen dengan asumsi variabel tangible asset, firm size, operating leverage, profitabilitas, dan growth sales dianggap konstan. Secara teoritis hal ini berarti bahwa semakin besar likuiditas (asset) perusahaan maka struktur modalnya (dalam hal ini utang) akan semakin bertambah, karena perusahaan yang mempunyai total aktiva yang besar kemampuan untuk membayar utangnya pun lebih besar. Namun, hasil penelitian ini tidak konsisten dengan penelitian Ozkan (2001) yang mana pada penelitian Ozkan (2001) variabel likuiditas mempunyai pengaruh negatif terhadap struktur modal.

e. Variabel Growth Sales (GS).

Koefisien regresi growth sales sebesar 0,114; menunjukkan bahwa variabel growth sales berpengaruh positif (searah) terhadap struktur modal. Apabila variabel growth sales mengalami kenaikan sebesar satu persen, maka struktur modal juga akan mengalami peningkatan sebesar 11,4 persen dengan asumsi variabel tangible asset, firm size, operating leverage, profitabilitas, dan likuiditas dianggap konstan. Hasil penelitian ini konsisten dengan penelitian Sartono dan Sriharto (1999) yang mana variabel growth sales mempunyai pengaruh dengan struktur modal.

f. Variabel Profitabilitas (NPM)

Koefisien regresi profitabilitas sebesar -0,234; menunjukkan bahwa variabel profitabilitas berpengaruh negatif (berlawanan arah) terhadap struktur modal. Apabila variabel profitabilitas mengalami kenaikan sebesar satu persen, maka struktur modal akan mengalami penurunan sebesar 23,4 persen dengan asumsi variabel tangible asset, firm size, operating leverage, growth sales, dan likuiditas dianggap konstan. 
Hasil penelitian ini konsisten dengan penelitian sebelumnya Rajan \& Zingales (1995), Ozkan (2001), Sartono dan Sriharto (1999) yang mana pada penelitian sebelumnya profitabilitas mempunyai pengaruh negatif dengan struktur modal.

\section{SIMPULAN}

Berdasarkan hasil penelitian, maka dapat diambil beberapa kesimpulan sebagai berikut:

a. Secara simultan terdapat pengaruh yang signifikan antara variabel Struktur Modal (DTA) dengan Tangible Asset (FTA), Firm size (SIZE), Operating leverage (DOL), Profitabilitas (NPM), Likuiditas (CR), dan Growth Sales (GS).

b. Secara parsial terdapat lima (5) variabel independen yang berpengaruh signifikan terhadap variabel dependen yaitu variabel Tangible asset (FTA), Firm size (SIZE), Profitabilitas (NPM), Likuiditas (CR) dan Growth Sales (GS). Sedangkan variabel Operating leverage (DOL) secara parsial tidak berpengaruh signifikan terhadap Struktur Modal (DTA).

c. Variabel Likuiditas (CR) mempunyai pengaruh negatif yang paling dominan terhadap struktur modal (DTA). Secara teoritis hal ini berarti bahwa semakin besar likuiditas (total asset) perusahaan maka struktur modalnya (dalam hal ini utang) akan semakin berkurang, karena perusahaan yang mempunyai total aktiva yang besar kemampuan untuk membayar utangnya pun lebih besar.

\section{DAFTAR PUSTAKA}

Adisetiawan. R., dan Asmas, Denny., 2012, Hubungan EVA dan MVA sebagai Alat Pengukur Kinerja Perusahaan Serta Pengaruhnya Terhadap Harga Saham, Jurnal Ilmiah Universitas Batanghari, 12(1), $12-18$

Adisetiawan, R., 2011, Pengaruh Kebijakan Modal Kerja terhadap Return on Investment pada Industri Semen di Bersa Efek Indonesia Periode 2003-2010, Jurnal Ilmiah Universitas Batanghari, 11(3), 7682

Asmas, Denny., 2016, Pengaruh Hubungan Partisipasi Anggaran terhadap Kinerja Manajerial dengan Komitmen Organisasi sebagai variabel Intervening (Studi Empiris pada Manulife Financial Indonesia), Jurnal Ilmiah Universitas Batanghari, 16(3), 19-29

Awat, J. Napa, Mulyadi, 1990, Keputusan-keputusan Keuangan Perusahaan (teori dan hasil pengujian empirik), Liberty, Yogyakarta.

Brigham, F. Eugene, Gapenski C. Louis, Philip R. Daves, 1999, Intermediate Financial Management, Sixth Edition, The Dryden Press.

Gujarati, D., 2006, Basic Econometrics, Third Edition, Mc-Graw Hil, Inc.New York.

Harris, Milton and Artur Raviv, 1991,"The Theory of Capital Stucture", The Journal of Finance, Vol. 46 No.1 March : 297:355.

Husnan, Suad, 2008, Manajemen Keuangan Teori dan Penerapan, Buku Satu, Edisi Keempat, BPFE, Yogyakarta.

Myers, Stewart C., 1984, “The Capital Structure Puzzle”, The Journal of Finance, Vol. 39 No. 3, July : 575592.

Ozkan, Aydin., 2001, "Determinants of Capital Stucture and Adjustment to Long Run Target : Evidence from UK Company Panel Data", Journal Business Finance \& Accounting, March : 175-198.

Rajan, R. G. and Zingales, 1995, "What Do We Know About Capital Structure? Some Evidence from International Data", The Jounal of Finance, Vol. 50, December : 1421-1459.

Riyanto, Bambang, 2001, Dasar-dasar Pembelanjaan Perusahaan, Edisi Keempat, Yayasan Badan Penerbit Gajah Mada, Yogyakarta

Sartono, Agus, Ragil Sriharto, 1999, "Faktor-faktor Penentu Struktur Modal Perusahaan Manufaktur di Indonesia", Sinergi Vol. 2 No. 22.

Sartono, R. Agus, 2001, Manajemen Keuangan (Teori dan Aplikasi), Edisi Keempat, Cetakan Ketujuh, BPFE, Yogyakarta.

Sutrisno, 2003, Manajemen Keuangan (Teori, Konsep dan Aplikasi), Edisi Pertama, Cetakan Kedua, Ekonisia, Yogyakarta. 
Weston, J. Fred, Eugene F. Brigham, 1999, Manajemen Keuangan, Terjemahan Wahana, Jaka A, Jilid Dua, Binarupa Aksara, Jakarta. 